\title{
Prerequisites of Gold-Mining Cluster Formation in Russia
}

\author{
Alexander V. Koneva, Victor A. Makarova, \\ Kristina A. Shulgina ${ }^{b}$, Svetlana F. Bogdanovskaya ${ }^{b}$, \\ Zhenni V. Mironova ${ }^{* b}$ and Lyudmila N. Kuzina ${ }^{b}$ \\ ${ }^{a} I T G$ «VOSTOK» Ltd \\ 8 a Nikitina Str., Krasnoyarsk, 660022, Russia \\ ${ }^{b}$ Siberian Federal University \\ 79 Svobodny, Krasnoyarsk, 660041, Russia
}

Received 01.03.2017, received in revised form 17.05.2017, accepted 14.09.2017

The article is devoted to the analysis of geographical, geological, technological and economic prerequisites of creation of a gold mining cluster in Russia as one of the organizational forms promoting consolidation of material, financial and personnel resources for implementation of technological innovations, in particular preliminary beneficiation in the developed modern conditions.

Keywords: mineral and raw materials sources, gold mining enterprises, efficiency, preliminary beneficiation, innovation.

Citation: Konev A.V., Makarov V.A., Shulgina K.A., Bogdanovskaya S.F., Mironova Zh.V., Kuzina L.N. Prerequisites of goldmining cluster formation in Russia, J. Sib. Fed. Univ. Eng. technol., 2017, 10(7), 940-951. DOI: 10.17516/1999-494X-2017-107-940-951.

(c) Siberian Federal University. All rights reserved

* Corresponding author E-mail address: mirgenni@yandex.ru 


\title{
Предпосылки для формирования \\ золотодобывающих кластеров в России
}

\author{
А.В. Конев ${ }^{\text {a }}$ В.А. Макаров ${ }^{a}$, К.А. Шульгина \\ С.Ф. Богдановская ${ }^{\tilde{0}}$ Ж.В. Миронова ${ }^{\sigma}$, Л.Н. Кузина ${ }^{\sigma}$ \\ ${ }^{a} \mathrm{OOО} \mathrm{ИТГ} \mathrm{«ВОСТОК»}$ \\ Россия, 660022, Красноярск, ул. Никитина, 8 а \\ ${ }^{6}$ Сибирский федеральный университет \\ Россия, 660041, Красноярск, Свободныий, 79
}

Статья посвящена анализу географических, геологических, технологических и экономических предпосылок создания золотодобывающего кластера в России как одной из организационных форм, способствующих консолидации материальных, финансовых и кадровых ресурсов для реализации технологических инноващий, в частности предварительного обогащения в сложившихся современных условиях.

Ключевыеслова:минерально-сырьеваябаза, золотодобывающиепредприятия, эффективность, предварительное обогащение, новащии.

\section{Introduction}

Given that the choice of profitability sources of metal is continuously shrinking, enhanced the influence of the quality of the mineral and raw materials sources (MRMS) and the price of the metal, in front of the gold mining industry there is a sharp problem of perfection of technology due to the transition to a new technological order, in particular due to the preliminary beneficiation. It will provide the processing of raw materials with low content of gold at an acceptable cost-effectiveness, both for investors and for the subsequent development of the industry.

However, the use only of technological innovation without organizational changes will not allow gold mining enterprises fully realize the received technological advantages. The solution of this problem would be to create the gold clusters.

\section{The economic and political importance of gold mining}

Gold is specific minerals, means of accumulation and preservation of national wealth, security and sovereignty of States. Gold is a specific mineral, means of accumulation and preservation of wealth, security and sovereignty of States. This implies that government policy must include specific measures to control and regulate the industry. On the other hand, the gold mining company (GMC) carrying on business for profit $(\Pi)$ defined by the expression $[1,2]$

$$
\Pi=\mathrm{S} \cdot \mathrm{T} \cdot Э
$$

where $\mathrm{S}, \mathrm{T}$ and $Э$ - parameters due to the quality of the feedstock, process efficiency extract from it the metal and the economy as a whole production.

$$
\begin{aligned}
& \mathrm{S}=\mathrm{C}(1-\mathrm{R}), \\
& \mathrm{T}=\mathrm{Q} \cdot \mathrm{J}(1-\mathrm{P})(1-\mathrm{W}),
\end{aligned}
$$




$$
\text { Э=Ц }-3 .
$$

In the equations (2) - (4) the $\mathrm{Q}$ - the volume of the rock mass production per unit of time, $\mathrm{C}$ - the average metal content contoured reserves, the $\mathrm{R}$ - dilution of broken rock mass, $\mathrm{J}$ - through extraction from it metal, $\mathrm{P}$ - its losses during the recess, and processing, 3 and Ц - production costs and metal extraction and the unit price, the $\mathrm{W}$ - integral index, which takes into account the probability of finding a mining facility in working order, including due to accidents.

From the expressions (1) - (4) shows that the effectiveness of the Gold Mining Industry (GMI) is determined by the quality of the mineral and raw materials sources (MRMS), technological level and economies of production, which depends not only on interior but also on external factors, metal prices and exchange rates, generated speculative gold market and geopolitical circumstances.

It should be noted a certain imbalance in the interests of the State responsible for national security and the owner of the subsoil and the (GMC) - exploit them, managing the extraction of the metal at its own discretion and in its own interests.

\section{Condition of gold mineral resource base.}

GMI Russia developed extensively the last 15-20 years, increasing the production of metalworking off previously explored fields, the development of new ore processing technologies (Table 1).

World production of gold also increased due to the implementation of projects of deposits development with sufficiently high metal content and the commissioning of new processing facilities (Table 2).

Table 1. Dynamics of production of gold in Russia for years (in tons and in percent relative increase in the previous year)

\begin{tabular}{|c|c|c|c|c|c|c|c|c|c|c|c|}
\hline 2000 & 2005 & 2006 & 2007 & 2008 & 2009 & 2010 & 2011 & 2012 & 2013 & 2014 & 2015 \\
\hline 143 & 168 & 164 & 163 & 184 & 205 & 203 & 211 & 225 & 255 & 289 & 293 \\
\hline 1,0 & $+17,5$ & $-2,4$ & $-0,6$ & $+12,9$ & $+11,4$ & $-1,0$ & $+3,9$ & $+6,6$ & $+13,3$ & $+13,3$ & $+1,4$ \\
\hline
\end{tabular}

Table 2. Structure of the production and consumption of gold in the world in the period $1970-2012$ (World Cold Council - gold.org)

\begin{tabular}{|l|c|c|c|c|c|c|c|c|c|}
\hline \multicolumn{1}{|c|}{ Indexes } & 1970 & 1975 & 1980 & 1984 & 1994 & 1996 & 2005 & 2006 & 2012 \\
\hline All gold mining (tons) & 1252,7 & 910,2 & 895,7 & 1058,5 & 2209 & 2284 & 2450 & 2500 & 2613 \\
\hline On jewelry & 1066 & 516 & 127 & 819 & 2604 & 2807 & 2709 & 2190 & 1908 \\
\hline On prosthetic dentistry & 58 & 63 & 64 & 51 & 52 & 55 & 62 & 60 & 40 \\
\hline In coins and medals & 91 & 272 & 201 & 174 & 75 & 60 & 37 & 45 & 315 \\
\hline Electronics & 89 & 66 & 89 & 122 & 192 & 207 & 273 & 312 & 303 \\
\hline Other use (ingots and ETF) & 62 & 57 & 66 & 53 & 200 & 348 & 646 & 663 & 1306 \\
\hline Total consumption & 1366 & 974 & 547 & 1219 & 3361 & 3477 & 3727 & 3270 & 4406 \\
\hline $\begin{array}{l}\text { The average price of gold, in } \\
\text { \$per 1 g }\end{array}$ & 1,0 & 4,2 & 19,7 & 13,0 & 11,9 & 12,5 & 14,2 & 19,3 & 54,1 \\
\hline
\end{tabular}


Now projects with high gold content practically none. There has been a steady trend of depletion and deterioration of the quality of MRMS (Fig. 1) [3].

From 1970 to 2010, the gold content in such kinds of stocks decreased from 12 to $1.8 \mathrm{~g} / \mathrm{t}$ (Fig. 1 Red line), that is 7 times or an average of 0.2-0.3 g / $\mathrm{t}$ annually. In the explored reserves (Fig. 1 - Blue line) gold content dropped from $5.5 \mathrm{~g} / \mathrm{t}$ in 1950 to $2 \mathrm{~g} / \mathrm{t}$ in 1970 and up to $0.76 \mathrm{~g} / \mathrm{t}$ in 2010.

The balance is now being handled holdings of major deposits of gold content varies from $2,0 \div 3,0 \mathrm{~g} / \mathrm{t}$. And with the launch of the 35 largest projects implemented in the world for processing raw materials involved with the content already $0,2 \div 1,0 \mathrm{~g} / \mathrm{t}$ (14 projects or $40 \%$ of the total); $1.0-2.0$ $\mathrm{g} / \mathrm{t}$ (10 projects $-29 \%$ ) and only 11 projects (31\%) provide for the processing of richer ores (Table 3 ).

The primary deposits of the metal are in the form of individual nests, inclusions and veins. The role of secondary deposits (placer deposits derived from primary deposits as a result of destruction of rocks under the influence of geological, atmospheric and hydrological processes) is continuously declining as their mining.

More than $42 \%$ of the world gold reserves are concentrated in the fields of metamorphic golduranium conglomerate, the largest of which is the Witwatersrand in South Africa and Jacobina in Brazil and Tarkwa in Ghana. Localization of the largest of them - the Witwatersrand in the orebearing area of $350 \mathrm{~km}$ and a width of $25-100 \mathrm{~km}$ with an average metal content of about $11 \mathrm{~g} / \mathrm{t}$.

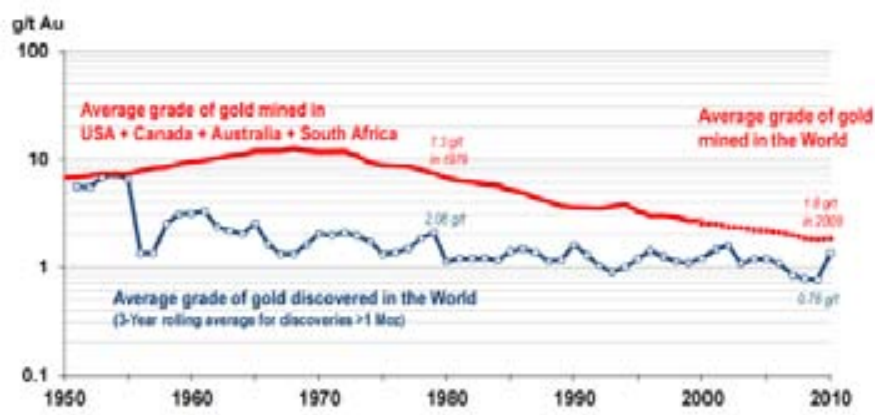

Fig. 1. The content of gold in mineral deposits

Table 3. The content of gold in the main world mining projects of various geological and industrial types [4]

\begin{tabular}{|c|c|c|c|c|c|c|}
\hline \multirow{2}{*}{ № } & \multirow{2}{*}{$\begin{array}{c}\text { Interval of } \\
\text { maintenances of } \\
\text { gold in a deposit, g/t }\end{array}$} & $\begin{array}{c}\text { Vulcano } \\
\text { plutonic belt }\end{array}$ & $\begin{array}{c}\text { Greenstone } \\
\text { belts }\end{array}$ & $\begin{array}{c}\text { Auriferous } \\
\text { conglomerates }\end{array}$ & $\begin{array}{c}\text { Terrigenous- } \\
\text { carbonate } \\
\text { strata }\end{array}$ & $\begin{array}{c}\text { Carbonaceous- } \\
\text { terrigenous strata }\end{array}$ \\
\hline 1 & $0,2-0,5$ & $4(11,4)$ & - & - & $1(2,9)$ & - \\
\hline 2 & $0,5-0,7$ & $3(8,6)$ & $1(2,9)$ & - & - & - \\
\hline 3 & $0,7-1,0$ & $4(11,4)$ & $1(2,9)$ & - & - & - \\
\hline 4 & $1,0-1,5$ & $3(8,6)$ & $3(8,6)$ & - & - & - \\
\hline 5 & $1,5-2,0$ & $1(2,9)$ & $1(2,9)$ & $1(2,9)$ & - & $1(2,9)$ \\
\hline 6 & $2,0-17$ & $2(5,7)$ & $1(2,9)$ & $5(14,3)$ & $1(2,9)$ & $2(5,7)$ \\
\hline Total & & $17(48,6)$ & $7(20,0)$ & $6(17,1)$ & $2(5,7)$ & $3(8,6)$ \\
\hline
\end{tabular}




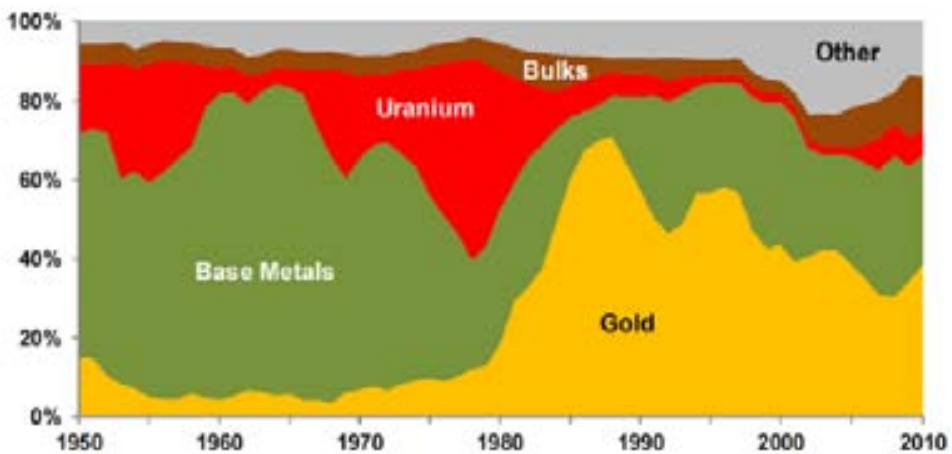

Fig. 2. The distribution of costs for exploration of different metals in the world [7]

A Little bit more than $10 \%$ of the gold reserves accounted for hydrothermal and epithermal goldsilver and goldtelluride mineral deposits: Dukat, Mnogovershinnoe and Amethyst in Russia, Lihir and Porgera in Papua New Guinea, Round Mountain in the United States. Approximately $7.2 \%$ of the gold reserves is in the mineral deposits of ancient greenstone belts: Kolar in India, Kalgoorlie in Australia, Parkyupayn Hemley in Canada. Approximately $6.3 \%$ of the gold reserves amount to stringer-disseminated hydrothermal deposits: Sukhoi Log and Nezhdaninskoe in Russia, Muruntau in Uzbekistan, Houmstayk in the United States and Ashanti in Ghana [5].

The structure of developed mineral deposits is changing with time. Reduced share of gold-bearing conglomerates, increased - of large gold-copper-porphyritic and gold-silver deposits, which is associated with working off of deposits on the surface, with the development of deposits in clastic strata, promoting geological prospecting (GP) and mining operations to a depth of 3-4 km (Table 3) [6].

In the foreseeable future gold production is also associated with the search and geological exploration of its deposits in the earth's crust, which spent from 30 to $70 \%$ of all of the resources in the last 30-35 years (Fig. 2).

However, despite the impressive cost and expand the geography of search, gold reserves growth is ensured in recent years mainly the exploration of ore fields, adjacent to the fields exploited or spent, with more and more low metal content. However, despite the impressive cost and expand the geography of search, gold reserves growth is ensured in recent years is mainly the exploration of ore fields, adjacent to the fields exploited or spent, with more and more low metal content. The probability of discovery of new large and rich gold deposits on the surface continuously decreases, despite significant not surveyed areas in Siberia and the Far East. The exploring complicates by dispersion, geological and technological diversity, and harsh climatic conditions.

\section{State gold mining technology}

Despite the depletion of MRMS and permanent economic crisis, gold consumption is growing. From 1970 to 2012 by 3.3 times, including by increasing its use in jewelry production - by 1.8 times, in the electronics industry -3.4 times, metal accumulation in the form of bullions and coins by financial and investment organizations - in 10.6 times (Table 2).

According to experts, with the annual production of gold in 2500-2700 tonnes and consumption in 3200-4500 tonnes of its global reserves will be exhausted within 30-40 years. MRMS major producing 
countries will provide them in the next 15-20 years at the level of production of metal more than 200 tons each, and then the inevitable will happen production decline. This forecast is partly confirms the decline in world gold production in the second and third quarters of 2016 for the first time in the last five years and the continuation of this trend should maintain or increase the current metal prices [8].

Depletion of MRMS accelerates gold mining open pit using high-performance mining equipment from large deposits with low gold content. With this method, $65 \%$ of the projects are being implement today, while investing in them exceed those for underground mining tripled. However, the more complex and expensive way to mine production, surpassing the capital intensity of the open method of 1.8-2.0 times, but noticeably higher than his average gold grade of the ore, not to the past. All noticeable trend of combining it with the open pit mining of deposits at the same time or with a slight time lag (20-25\% of all gold mining projects implemented), allowing you to use capital more efficiently.

In general, formed a steady trend of rentable development of the poor and refractory ores with a variety of technological solutions, from heap leaching to complex schemes with deep enrichment of raw materials.

GMI Russia develops spontaneously, mainly through the efforts of private GMC. The rate of reproduction of the stocks declined to the level of $60-80 \%$, including trough the reduction of exploration funding, while the pace of construction of processing facilities in recent years have almost doubled and reached $80 \mathrm{mln}$. tons per year. Volumes of the rock mass is increasing rapidly, but the increase in gold production is much more modest, reflecting the low efficiency of investment, involvement in the processing ever more of poor ore, reserves of below standard and off-balance raw.

\section{Condition of gold mining economy}

The drop of the price of gold in 2013 to the level of 1900 to 1200 / troy ounce (t.o.) (Fig. 3) exposed the negative circumstances of GMI Russia, including low planning "gap" between the price and production cost of $10-15 \%$, corresponding to the ratio of costs to price 3/Ц about 0.9 [1]. This prompted the Bank of Russia to a change macroeconomic conditions weakening of the ruble rate against the dollar, users of entrails of the earth - to reduce operating costs, "freezing" and sale of not profile assets, and a budgets reduction of exploration, reducing the rate of reproduction of reserves, investment ratings of companies, increasing capital investment risks.

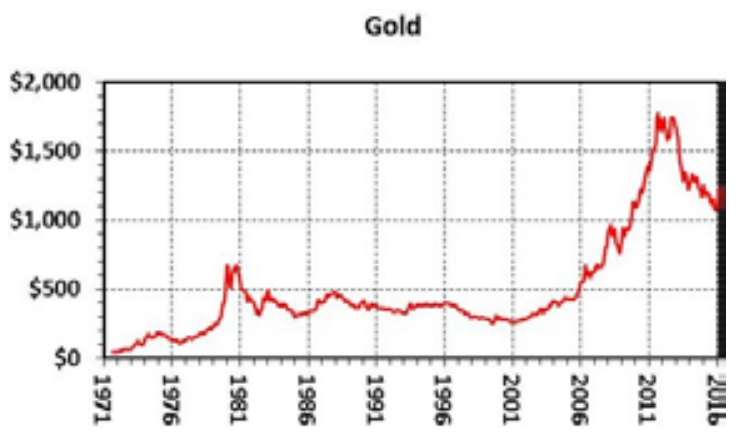

Fig. 3. The dynamics of the gold price in 1971-2016 period

$$
-945-
$$


Research has shown that if the cost price does not exceed $50 \%$, than a reduction of $10 \%$ in the price will result a fall of profits no more than $25 \%$. When the share of the costs is above $80 \%$ the same level of price reduction will "bring down" the gross profit of the company by $50-100 \%$ [1]. A prime example is the story of the development of the Natalka miniral deposit, which started in 2011 with a projected cost in $1600 \$ /$ t.o. with the price of gold in the range 1800-1900 \$ / t.o, but was suspended in summer 2014 due to the drop of price to the level of 1200 \$ t.o.

Thus, a key factor in the development of GMI becomes quality of MRMS, characterized by the size of the reserves, territorial accessibility and depth of their occurrence, power and technological properties of ores and the main indicator - the average metal content. Processing poor and refractory ores using sophisticated technologies increases the cost and loss of the metal, reduces profitability of processing, strengthening a dependence of the gold economy not only from the quality of MRMS, but also of the price.

Given that the choice of rentable sources of metal is shrinking continuously, the impact of MRMS price and quality can be reward only by reducing capital and operating costs, improving technology and the transition to a new technological order, which will provide the raw material processing with a gold content at $0.5-1.0 \mathrm{~g} / \mathrm{t}$ with an acceptable profitability.

\section{Possibilities of increasing the efficiency of the gold mining companies}

Companies react to adverse fluctuations of prices and exchange rates escalating volumes of extraction and processing of ores, increased metal content in raw selective extraction, the current measures for reducing the production costs, including exploration.

Opportunities to increase production capacity are limited by power of dressing and metallurgical industries and their expansion requires significant resources and time. So the ratio of capital expenditure for the construction of the mine and the processing complex is about 1:3 to open-pit mining (from the underground - a 1:1), with the metallurgical beneficiation concentrates $-1: 4$ or more (according to underground mining - in the range of 1:2 to 1:3). Consequently, the operational capacity of metal production with minimal costs is only possible selective mining of the rich and high-quality ore, but is acceptable only as a temporary solution: in a crisis, at the peak of the repayment of debt, due to the technological need, etc. Long-term use leads to its accumulation in the warehouses of the poor and sub-standard (off-balance) ores, which may partially mixed with to ores of current production during periods of high gold prices, but generally require additional expenses for the organization of their processing.

Within 2-3 years a metal production can be extended with eligible costs, involving in working off inventory of below-standard and off-balance materials with crushing and screening the pre-enrichment systems (PE), as well as the excretion of the breed and processing of concentrates produced by heap leaching (HL).

Capital and operating costs for the organization of the software are comparable to those for offices ore preparation concentrators. Costs for the construction of installations HL usually do not exceed 30$40 \%$, while operating costs $-60-70 \%$ of those in the case of processing of raw materials on the standard metal enrichment and extraction by bio leaching and lixiviation in digesters of concentrate froth.

In Russia, there is not any large-scale and successful experience in industrial application PE gold ores. A gold recovery HL varies between $55-75 \%$. $[9,10]$.

$$
-946-
$$


The use of HL is also limited by economic expediency of ore pretreatment by crushing pelletizing raw materials with the content of $1.0 \mathrm{~g} / \mathrm{t}$ and up. For the rock mass (from the stripping zone of contact "ore body - the host rocks", internal layers, dykes, etc.) with a metal content of $0.5-0.7 \mathrm{~g} / \mathrm{t}$ ore preparation is generally unprofitable. However, without it extracting falls to level of $50-60 \%$ and lower.

In Siberia and the Far East HL becomes complicated with climatic conditions, where the installation operate no more than 6-9 months of the year, requires heating the reactants, the use of coatings, that ensures the temperature in the heap is not below $-3{ }^{\circ} \mathrm{C}$, reducing an entering the precipitation. In remote areas, the use of HL is complicated with lack of infrastructure, logistics, with deficit of qualified personnel. In addition, because of the danger to personnel and the environment HL requires high production discipline, controlled by the supervisory authorities.

These shortcomings are lacking in intensive cyanide processes of the ore material (middlings of gravity dressing of ores in centrifugal concentrators, cleaning on concentration tables, etc.) size of less than $2 \mathrm{~mm}$ and a gold content of $100 \mathrm{~g} / \mathrm{t}$ and up to special leaflet devices (reactors with saturation pulp with oxygen, hydrogen peroxide, ozone, sometimes is heated up to temperatures of $\left.60-90{ }^{\circ} \mathrm{C}\right)$.

Adverse circumstances do not constitute a complete reduction of capital investment in new mining projects, as it will stop the growth of production, will have a negative impact on the investment attractiveness of companies.

During the period from 2013, GMC almost exhausted interior, seek external opportunities to increase its reserves, reduce costs, mainly by companies merger into larger holdings, associated with use of organizational and technological innovation, has not yet practiced.

A reducing of costs, an increase of profitability and competitive advantages of the group of companies cluster provides their organizations through the optimal placement and cooperative mining and processing industries, service and engineering centers, which focused on certain area. Compared with the holding cluster, combining the interests of its members facilitates the consolidation of material, financial and human resources.

Cluster form covered about half of the global economy. According to the Global Competitiveness Index of the World Economic Forum (Global Competitiveness Index-GCI), Russia in terms of development of clusters takes 124 place out of 148, behind far not only from US, Germany and France, but also of members of the BRICS: India is at 16, China - 24 and Brazil - 26 place. According to the Russian Cluster Observatory, Institute for Statistical Studies and Economics of Knowledge in Russia there are more than 100 clusters at different stages of development and with different crucial specialization. Their development is stimulated by the state (the Russian Federation Government of 01.28.2016, the number 41, etc.) [11, 12].

For the formation of gold clusters in Russia, there are geographical, geological, technological and economic conditions.

The main gold provinces in Russia are scattered in Siberia and the Far East in the territories stretching for 5-10 thousand $\mathrm{km}$, in places, to develop which require very heavy even leading GMC investments in infrastructure and logistics, in the construction of mining and processing facilities. On the other hand, macroeconomic situation makes the GMC to get rid of non-core assets and functions, sale and transfer them to outsource (prospecting and exploration, field 
development, infrastructure creation, introduction of drilling and drilling and blasting operations (DBO), logistics, etc.).

Exploration experience in the Natalka field and Sukhoi Log, and Olimpiada Nezhdaninskoe indicates that the related with them metallogenic province forms in closed ore-forming systems, identification feature which is concentric structure, dimensions, and three-tier structure. In the center is there "nuclear" concentration zone, surrounded by "transit" area of lower grades of gold, surrounded in turn "front" area of higher concentrations. The geological structure of ore-forming systems and geography metallogenic province determines the territorial location of mining and processing facilities, related infrastructure, logistics and service.

The degree of enrichment by gravity and flotation of hard raw materials does not exceed 5-15, accompanied by significant metal losses with tails. At the same time, the preliminary enrichment can provide the comparable indicators of wash ability with less metal loss. On the other hand, metallurgical processing of concentrates of enrichment within the small and medium GMC costly. So the expediency of integrating them into the structure of: crushing and screening equipment in the mines (quarries, mines), clustered processing plants, regional chemical and metallurgical plants with well-developed technology.

Experience shows that the clusters respond with more flexibility to changing market conditions, provide a cost-effective development of small and medium sized groups, remote and difficult fields of joint processing of their raw materials a single production center (the processing hub) with the effect comparable to working off a large deposit.

However, it is difficult to imagine large-scale introduction of clusters without the participation of the state, because the need of effective field development control mechanisms, deterring spontaneous development of GMI, compliance with environmental requirements, standards of responsibility to the shareholders of the GMC, the state and employees.

The State limit oneself to measures of legal regulation, trying to encourage them to subsoil management and full use of reserves, to the primary processing of complex ores with minimal loss of useful components. However, the effectiveness of mechanisms for review and approval by the authorized state bodies (Rosnedra, Rostekhnadzor) design and technical documentation for field development, approval standards losses of minerals during their extraction and primary processing, low. At the same time the mechanisms of financial sanctions, withdrawal of licenses, coordination of economic activity GMC producing strategically important for the national security of the metal in an unfavorable international situation for Russia, hardly used.

Finally, to achieve the goals declared by State is necessary to raise the technological level of GMI, and national security interests require not only foreign, but also domestic innovations, the creation of that require targeted funding priorities of scientific research and development work from centralized specialized funds, generated, including by GMC deductions.

The most promising known innovations in GMI seems the technology of preliminary enrichment of broken rock mass of size $-300+5 \mathrm{~mm}$ due to separation from it diluting rocks, using different physical methods, including the so-called radiometric enrichment (RE) [13, 14].

In theory, analysis of numerous results of bench and pilot tests, the long experience of the RE ores of deposits Muruntau, Kokpatas on Novoiyskom Mining and Metallurgical combine in Uzbekistan show the possibility of excretion to $70-90 \%$ of the rock [15-19], what will make possible:

$$
-948-
$$


Firstly, to increase the gold content in the feedstock by 3-5 and more times, with the extraction to $90-95 \%$ of the metal, with content of gold in the depleted product (pre-enrichment tails) up to $0.1-0.3 \mathrm{~g} / \mathrm{t}$;

Secondly, the reduction up to $50-60 \%$ of the total costs, improved cost-effectiveness by several times of the metal production;

Third, the up building with lower cost of the geological and exploration work, by reducing the cut-off grade of economically viable reserves of deposits;

Fourth, the decline at times of capital expenditures because in the scheme of preliminary enrichment increases by several times the power capacity of the mine regarding the power of dressingand-metallurgical treatment;

fifthly, decrease several times loads of the environment due to reduction of emissions of fine tails of enrichment, etc.

\section{Conclusions}

Thus, in GMI formed a range of problems, which resolution requires an accelerated implementation of organizational and technological innovation, strengthening the state's role as a catalyst and regulator of qualitative changes in GMI, a higher level of interaction between the State and business.

The main lines of organizational and technological innovations in this time can be:

1. The use of cluster forms of accommodation organization and cooperation of the mining and processing industries, service and engineering centers, concentrated on certain territory.

2. The use of the pre-enrichment, which will reduce significantly the cost of further processing of ore extraction and improve profitability, as well as the creation of additional mechanisms of stable functioning of the GMC, under de conditions of uncertainty with reserves, conditions of demand and market forces as a whole.

The economic effect of the proposed organizational and technological innovation is determined by the scale of it application in each case.

\section{References}

[1] Батугина Н.С. Изменение цен на минеральное сырье и эффективность работы горных предприятий. Минеральные ресурсы России. Экономика и управление, 2008, 6, 45-48 [Batugina N.S. Changes in prices of mineral raw materials and the efficiency of the mining enterprises. Mineral Resources of Russia. Economics and Management, 2008, 6, 45-48 (in Russian)]

[2] Конев А.В., Шульгина К.А., Богдановская С.Ф., Миронова Ж.В., Кузина Л.Н. Инвестиционное проектирование высокорентабельной отработки месторождений руд цветных металлов и золота с применением новаций рудоподготовки. Сборник докладов VII Международного конгресса «Цветные металль и минералы 2015», Красноярск, 2015, 13561363 [Konev A.V., Shulgina K.A., Bogdanovskaya S.F., Mironova J.V., Kuzina L.N. Investment highly profitable work on the deposits of non-ferrous metals and gold with the development of innovative ore dressing. Proceedings of the VII International Congress "Non-Ferrous Metals \& Minerals 2015», Krasnoyarsk, 2015, 1356-1363 (in Russian)]

[3] Исследование компании MinEx Consulting// www.finmatrix.ru/main/-116/2899/. [Research company MinEx Consulting// www.finmatrix.ru/main/-116/2899/ (in Russian)]

$$
-949-
$$


[4] Беневольский Б.И., Мызенкова Л.Ф. Глобализация мировых инвестиционных потоков в «золотые» проект. Минеральные ресурсы России. Экономика и управление, 2012, 6, 73-81 [Benevolsky B.I., Myzenkova L.F. Globalization of the world's investment flows in the «golden» project. Mineral Resources of Russia. Economics and Management, 2012, 6, 73-81 (in Russian)]

[5] Нефедов М.Д. Цена унции золота: производственный фактор роста. Альманах современной науки и образования, 2012, 10(65); http://www.gramota.net/materials/1/2012/10/42. html [Nefedov M.D. Price ounce of gold: the production of growth factors. Almanac of Modern Science and Education, 2012, 10 (65); http://www.gramota.net/materials/1/2012/10/42.html (in Russian)]

[6] Стружков С.Ф., Наталенко М.В. Уникальные золоторудные регионы Витватерсранд (ЮАР) и Центрально-Колымский (Россия) - сопоставительный анализ. Минеральныле ресурсы России. Экономика и управление, 2009, 4, 72-81 [Struzhkov S.F., Natalenko M.V. Unique gold ore regions of Witwatersrand (South Africa), and Central Kolyma (Russia) - a comparative analysis. Mineral Resources of Russia. Economics and Management, 2009, 4, $72-81$ (in Russian)]

[7] Девальвация в золотом эквиваленте// http://www.gold.1prime.ru/bulletin/analytics/show. asp?id =3803, 16.02.2016 г. [The devaluation of gold equivalent// http://www.gold.1prime.ru/bulletin/ analytics/show.asp?id =3803, 16.02.2016 (in Russian)]

[8] Несис В.Н. Золотодобываюшую отрасль ждет большая консолидащия// http:// izvestia. ru/news/637643, 21.10.2016 г. [Nesis V.N. Gold mining industry is waiting for a large consolidation // http:// izvestia. ru/news/637643, 21.10.2016 (in Russian)]

[9] Строганов Г.А., Шутов А.М. Критерии оценки пригодности минерального сырья для переработки методом кучного выщелачивания. Цветные металлы, 1996, 7, 4-6 [Stroganov G.A., Shutov A.M. Criteria for assessing the suitability of mineral raw materials for processing by heap leaching. Non-ferrous metals, 1996, 7, 4-6 (in Russian)]

[10] Татаринов А.П., Гудков С.С., Дементьев В.Е. Основные аспекты технологии кучного выщелачивания из золотосодержащего сырья// ОАО «Иргиредмет». Золотодобыча, 34, Сентябрь, 2001; http://zolotodb.ru/articles/technical/373 [Tatarinov A.P., Gudkov S.S, Dementiev V.E. Key aspects of the technology of heap leaching of gold ores // JSC «Irgiredmet». Gold mining, 34, September 2001; http://zolotodb.ru/articles/technical/373 (in Russian)]

[11] Наджафаров В.Н. Обзор зарубежного опыта внедрения кластеров. Вестник МГУ, 2009, 4, 36-43; http://vestnik-mgou.ru/Articles/Doc/4056 [Nadjafov V.N. The review of introduction of foreign clusters. Vestnik MGU, 2009, 4, 36-43; http://vestnik-mgou.ru/Articles/Doc/4056 (in Russian)]

[12] Анохина M.Е., Мочальников В.Н., Коростелев Д.Г. Кластерные технологии в системе управления региональным развитием. Российское предпринимательство, 2014, 9 (255), 62-74; https://bgscience.ru/lib/8533/ [Anokhina M.E., Mochalnikov V.N., Korostelev D.G. Cluster technology in regional development management system. Russian Entrepreneurship, 2014, 9 (255), 62-74; https:// bgscience.ru/lib/8533/ (in Russian)]

[13] Мокроусов В.А., Лилиева В.А. Радиометрическое обогащение нерадиоактивных руд. М.: Недра, 1979, 187 с. [Mokrousov V.A., Lilieva V.A. Radiometric enrichment of non-radioactive ores. M.: Nedra, 1979, 187 p. (in Russian)]

[14] Ревнивцев В.И., Рыбакова Т.Г., Леман Е.П. Рентгенорадиометрическое обогащение комплексных руд иветных и редких металлов. М.: Недра, 1990, 120 с. [Revnivtsev V.I., 
Rybakova T.G., Lehman E.P. X-ray radiometric enrichment complex ores of nonferrous and rare metals. M.: Nedra, 1990, 120 p. (in Russian)]

[15] Федоров Ю.О., Коренев О.В., Короткевич В.А. и др. Опыт и практика рентгенорадиометрической сепарации (РPC) золотосодержащих и других типов руд. Золотодобывающая промышленность, 2004, 4, 16-19 [Fedorov J.O., Korenev O.V., Korotkevich V.A. and others. The experience and practice of X-ray radiometric separation (PPC) gold and other ore types. Gold-mining industry, 2004, 4, 16-19 (in Russian)]

[16]ФедоровЮ.О.,КацерИ.У.,КореневО.В.идр. Опытипрактикарентгенорадиометрической сепарации руд. Известия высших учебных заведений. Горный журнал (Уральское горное обозрение), 2005, 5, 21-37 [Fedorov J.O., Katser I.U., Korenev O.V. and others. The experience and practice of X-ray radiometric separation of ore. Proceedings of the higher educational institutions. Mining Journal (Ural Mining Review), 2005, 5, 21-37 (in Russian)]

[17]МальгинО.Н.Основныетехнологическиерешенияпорудосепарациизолотосодержащей горной массы. Горный вестник Узбекистана, 2004, 3(18), 32-34 [Malgin O.N. The main technological solutions for rudoseparatsii gold-bearing rock mass. Mining Bulletin of Uzbekistan, 2004, 3(18), 32-34 (in Russian)]

[18] Конев А.В., Шульгина К.А., Миронова Ж.В. Проблемы переработки руд цветных металлов и золота с предварительным обогащением. Сборник докладов V Международного конгресса «Цветные металль 2013», Красноярск, 2013, 78-82 [Konev A.V., Shulgina K.A., Mironova J.V. Problems processing of non-ferrous metals and gold with pre-enrichment. Proceedings of the VInternational Congress «Non-Ferrous Metals 2013», Krasnoyarsk, 2013, 78-82 (in Russian)]

[19] Конев А.В., Шульгина К.А., Миронова Ж.В., Кузина Л.Н., Богдановская С.Ф. Проблемы разведки и оценки перспективности отработки месторождений руд цветных металлов и золота с применением предварительного обогащения. Сборник докладов VI Международного конгресса «Цветные металль и минераль 2014», Красноярск, 2014, 97-113 [Konev A.V., Shulgina K.A., Mironova J.V., Kuzina L.N., Bogdanovskaya S.F. Problems of the exploration and evaluation of ore deposits development prospects of nonferrous metals and gold using pre-concentration. Proceedings of the VI International Congress «Non-Ferrous Metals \& Minerals 2014», Krasnoyarsk, 2014, 97-113 (in Russian)] 